\title{
27
}

\section{Salt River Hydrological Study}

\author{
Colin Whittemore, Bryan Nicholson and Nadia Nitsche
}

The Salt River Canal discharges storm runoff from a $214 \mathrm{~km}^{2}$ catchment into Table Bay just north of Cape Town's city centre. The catchment includes a number of the northern and central suburbs of Cape Town as well as the eastern slopes of Table Mountain.

Concerns about the effects of urbanisation within the catchment in terms of increased stormwater runoff and decreased water quality led the city's Catchment, Stormwater and River Management Branch to appoint engineering and environmental consultants to assist in formulating a Catchment Management Plan for the Salt River Catchment. During the course of Phase 1 of the Management Plan formulation, the need for undertaking several specialist studies was identified (Sigma Beta, 2000). One of these was a detailed hydrological study that was necessary to evaluate the extent and risk of flooding of residential, commercial and industrial areas located in close proximity to the rivers of the catchment.

This chapter concentrates on Phase II of the hydrological study which included evaluation of storm runoff from the various sub-catchments forming the greater Salt River Catchment and the determination of 1:50 and 1:100 y

\footnotetext{
Whittemore, C., B. Nicholson and N. Nitsche. 2004. "Salt River Hydrological Study." Journal of Water Management Modeling R220-27. doi: 10.14796/JWMM.R220-27.

(C) CHI 2004 www.chijournal.org ISSN: 2292-6062 (Formerly in Innovative Modeling of Urban Water Systems. ISBN: 0-9683681-9-0)
} 
floodlines for certain of the watercourses within the catchment. The chapter outlines the methodology used, presents the results of the study and includes comments on some of the difficulties experienced and lessons learned during the course of the project.

A requirement of the study was that the hydrological modeling be undertaken using the Visual SWMM analysis software.

\subsection{Introduction}

The greater Salt River Catchment $\left(214 \mathrm{~km}^{2}\right)$ drains the Tygerberg Hills, a number of the northern and central suburbs of Cape Town as well as the eastern slopes of Table Mountain. Storm runoff from the catchment discharges into Table Bay, in the Atlantic Ocean, via the Salt River Canal at Paarden Island. Major tributaries contributing runoff to the Salt River include the Elsieskraal, Vygekraal, Kromboom, Black and Liesbeek Rivers. Figure 27.1 shows the lower reaches of the Black and Liesbeek Rivers together with the concrete-lined Salt River Canal discharging into Table Bay.

The main channels of the Vygekraal, Black and Liesbeek Rivers as well as the concrete-lined Salt River Canal flow full approximately once every two years. These events generally coincide with flooding of the River Club property at the confluence of the Liesbeek and Black Rivers (Figures 27.2 to 27.4).

In recent years, rainfall events causing this flooding have been limited in extent and have had recurrence intervals of between 1:2 y and 1:5 y. This indicates that more intense, catchment wide rainfall, of typically 1:50 y or 1:100 y recurrence interval, would result in widespread flooding of low-lying residential, commercial and industrial areas. This could also result in flooding of the city's two main arterial roads, the $\mathrm{N} 1$ and the N2, and the main railway routes from the city centre to the northern and southern suburbs.

One method of reducing the risk of flooding would be to widen the Salt River Canal. The need for this has been anticipated for many years with an enlarged servitude being provided through the industrial area of Paarden Island for this purpose. However, implementation of a project of this magnitude has to be based on sound hydrological and hydraulic analyses, assessment of alternative flood mitigating measures and economic assessment of the alternatives. To this end, the Catchment, Stormwater and River Management Branch of the City of Cape Town (CSRM) initiated the three-phased Salt River Hydrological Study. 


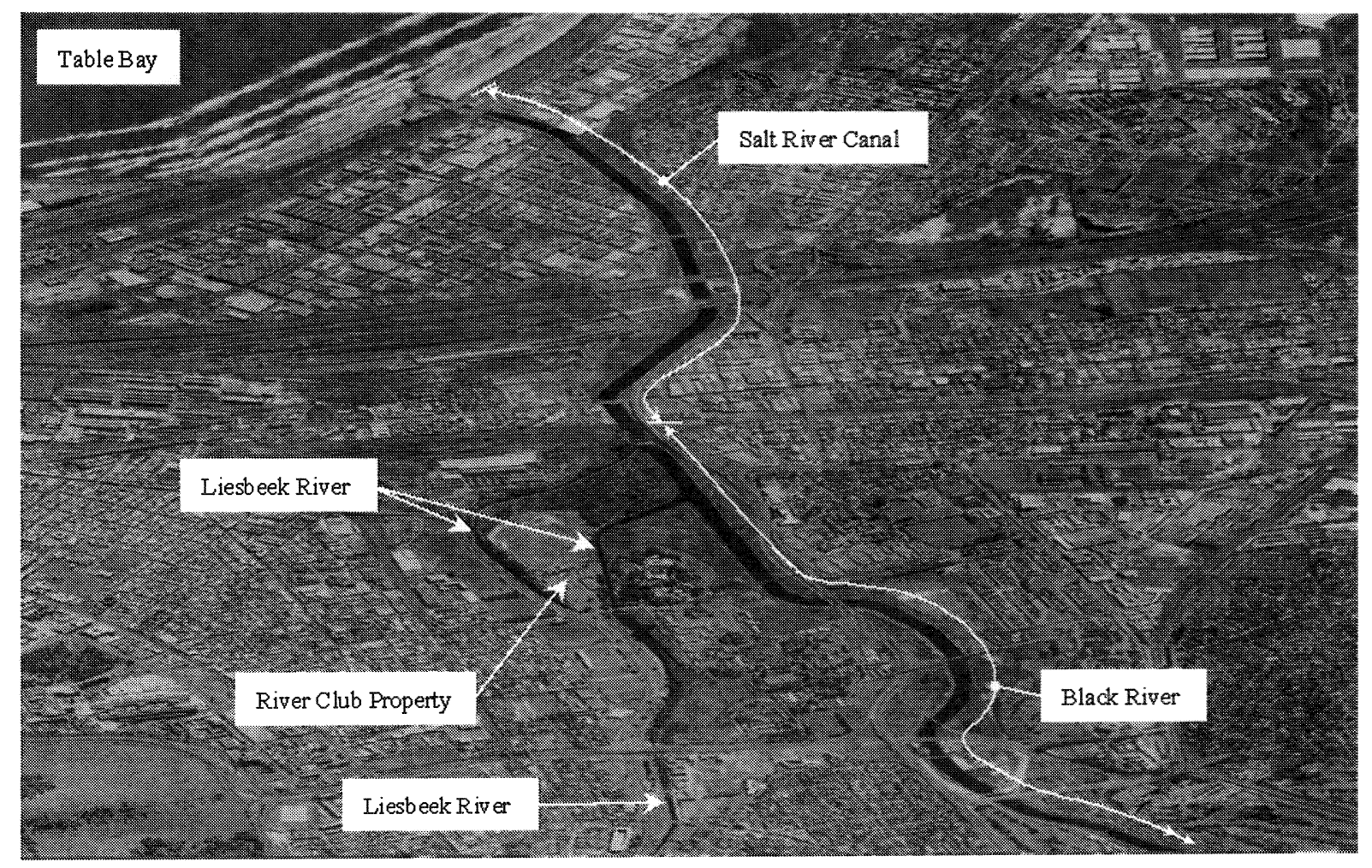

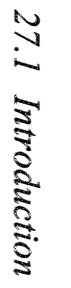

Figure 27.1 Lower reaches of Liesbeek and Black Rivers (foreground) with the Salt River Canal (background) discharging into Table Bay. 


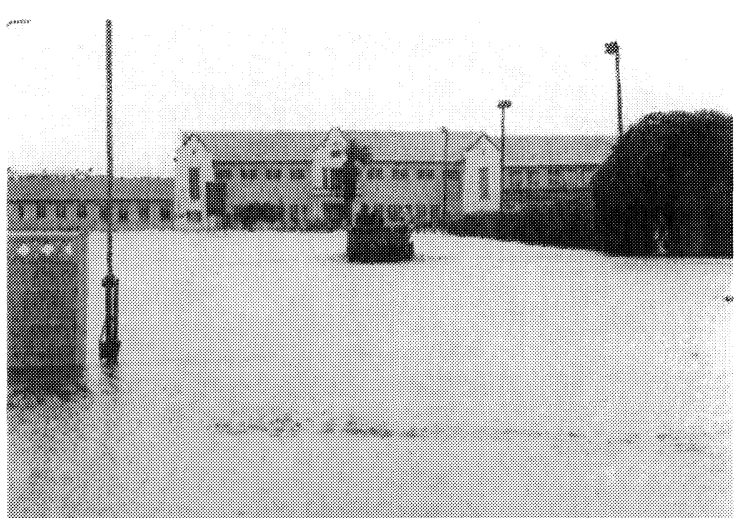

Figure 27.2 Flooding of River Club Property (Aug 2001).

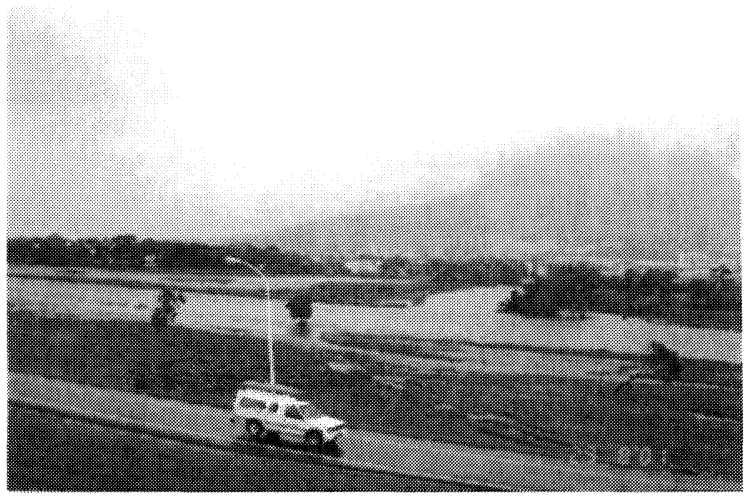

Figure 27.3 Confluence of Black and Liesbeek Rivers with overtopping of main channel (Aug 2001).

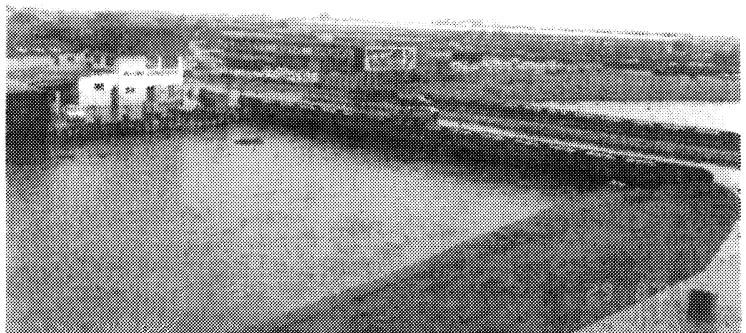

Figure 27.4 Salt River Canal flowing full (Aug 2001). 


\subsection{Study Phases, Teams and Tasks}

The phases of the Salt River Hydrological Study are summarised as follows:

Phase I: Gathering of information, reviewing of hydrological

parameters and evaluation of stormwater modeling tools with a view to making recommendations for Phase II of the study.

Phase II: Configuring and running of hydrological and hydraulic models, determination of floodlines and identification of flood risk areas (the subject of this chapter).

Phase III: This phase is still to be commissioned. It will include an investigation of measures that could be implemented to alleviate flooding in high-risk areas. It will also include economic analysis of potential flood damage and the viability and cost of implementing the various mitigating measures.

At the commencement of Phase II, seven firms of consulting engineers were appointed to carry out hydrological studies for the various Salt River subcatchments. The appointments were made after consultants had submitted prequalifying reports outlining their experience in the study area. This enabled the city to appoint consultants on the basis of existing knowledge and experience.

The following firms were appointed to carry out the hydrological studies:

- Africon - Bokmakierie sub-catchment $\left(4.2 \mathrm{~km}^{2}\right)$ and Maitland/ Kensington sub-catchments $\left(9.7 \mathrm{~km}^{2}\right)$

- Arcus Gibb - Vygekraal sub-catchment $\left(16.7 \mathrm{~km}^{2}\right)$

- BKS - Liesbeek sub-catchment $\left(26.0 \mathrm{~km}^{2}\right)$

- De Villiers Sheard - Blomvlei sub-catchment (11.4 km²)

- iCE Group - Langa, Jakkalsvlei and Kalksteenfontein subcatchments $\left(3.3 \mathrm{~km}^{2}, 17.9 \mathrm{~km}^{2}\right.$, and $10.5 \mathrm{~km}^{2}$ respectively)

- KFD Wilkinson - Black and Kromboom sub-catchments (5.7 $\mathrm{km}^{2}$ and $8.4 \mathrm{~km}^{2}$ respectively)

- Ninham Shand - Elsieskraal sub-catchment $\left(92.0 \mathrm{~km}^{2}\right)$ together with areas draining directly to the Salt River $\left(7.9 \mathrm{~km}^{2}\right)$.

These studies are reported in seven stand-alone reports (Africon, 2001; Arcus Gibb, 2001; BKS, 2001; de Villiers Sheard, 2002; iCE Group, 2002; KFD Wilkinson, 2001; Ninham Shand, 2002). Apart from the reports, the final submissions to the city included GIS coverages and databases together with the sub-catchment and river models. 


\subsection{The Greater Salt River Catchment}

The characteristics of the greater Salt River catchment vary considerably in terms of topography, rainfall, vegetation, soil type and land-use as one moves from the steep slopes of Table Mountain across the Cape Flats to the gentle slopes of the Tygerberg Hills. Land-use in the catchment includes afforestation, indigenous vegetation, residential areas (varying from low density, very affluent communities through to high density, very poor communities), commercial areas, industrial areas and farm lands.

Mean annual precipitation varies from approximately $1,000 \mathrm{~mm}$ on the slopes of Table Mountain to $500 \mathrm{~mm}$ in the Tygerberg area some $18 \mathrm{~km}$ to the east.

The headwaters of the Liesbeek and Elsieskraal Rivers are in their natural state but the rivers become increasingly degraded in a downstream direction as they drain the urbanized area. Most of the remaining tributaries of the Salt River are formalized into canals for part of or, in some instances, their entire lengths. Figures 27.5 to 27.8 show the variation in watercourse characteristics from the source of the Elsieskraal River to the mouth of the Salt River. Figures 27.9 and 27.10 show sections of the Bokmakierie and Liesbeek River canals.

\subsection{Modeling Parameters}

Phase I of the Salt River Hydrological Study (Ninham Shand, 2000) provided guidelines for the modeling parameters that were to be used in the Phase II studies.

\subsubsection{Rainfall}

The following details pertaining to single-event design storms were specified for Phase II of the study, on the basis of rainfall evaluated during Phase I:

- the SA-SCS Type 1 storm distribution was to be used;

- a $24 \mathrm{~h}$ storm duration was to be used;

- Adamson's 1:50 and 1:100 y 1-d rainfall depths were to be used (Adamson, 1983) or alternatively, data published by Smithers and Schulze (Smithers and Schulze, 2000) was to be used;

- areal reduction factors were to be applied (Alexander, 1991); and

- storm movement did not need to be considered. 


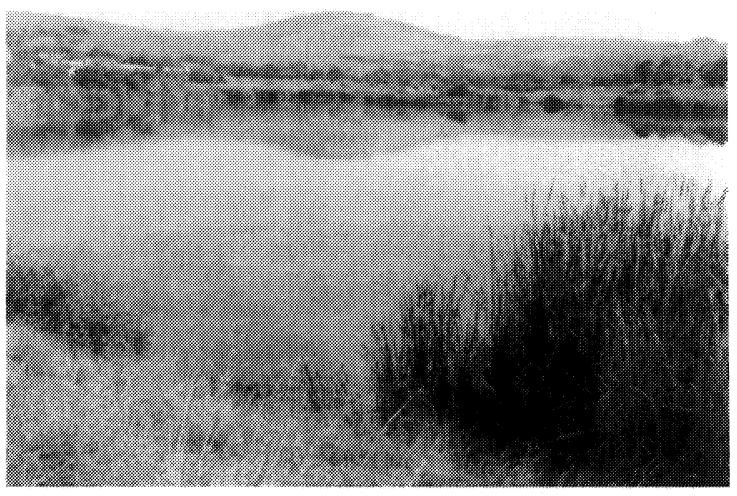

Figure 27.5 Door de Kraal Dam - Upper Elsieskraal Catchment, with farmlands.

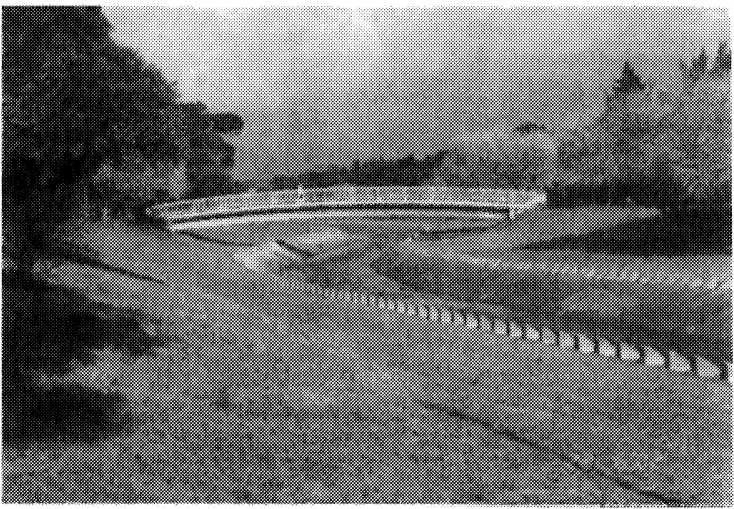

Figure 27.6 Canalised section of Elsieskraal River, with grassed flood plain.

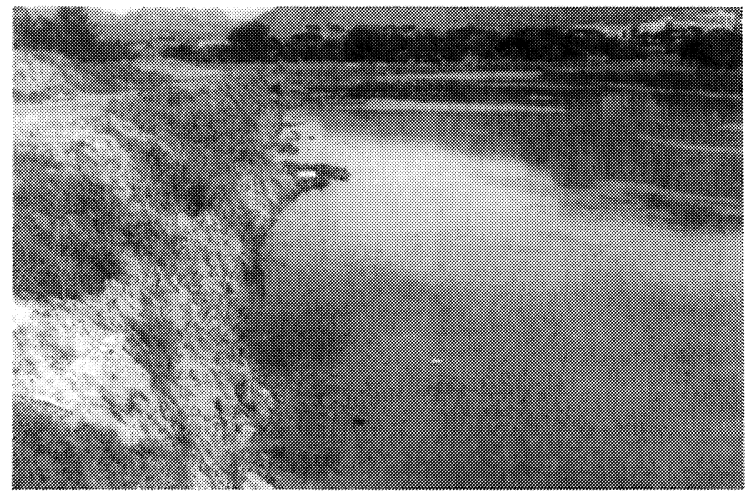

Figure 27.7 Unlined section of Vygekraal River (downstream of confluence with Elsieskraal River). 


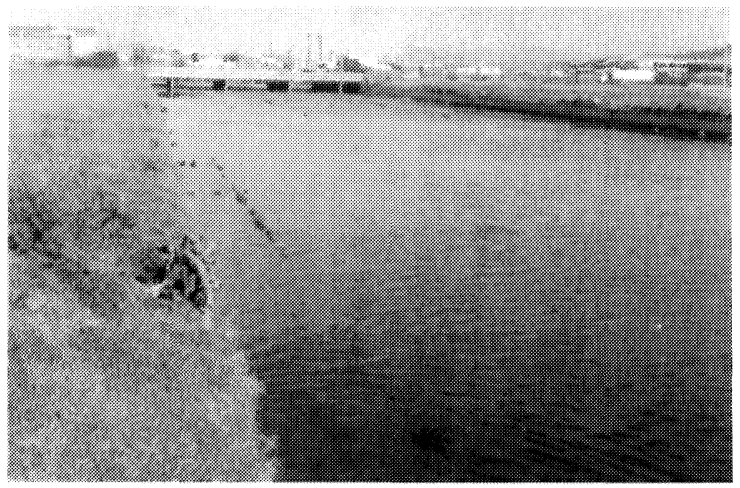

Figure 27.8 Canalised section of Salt River.

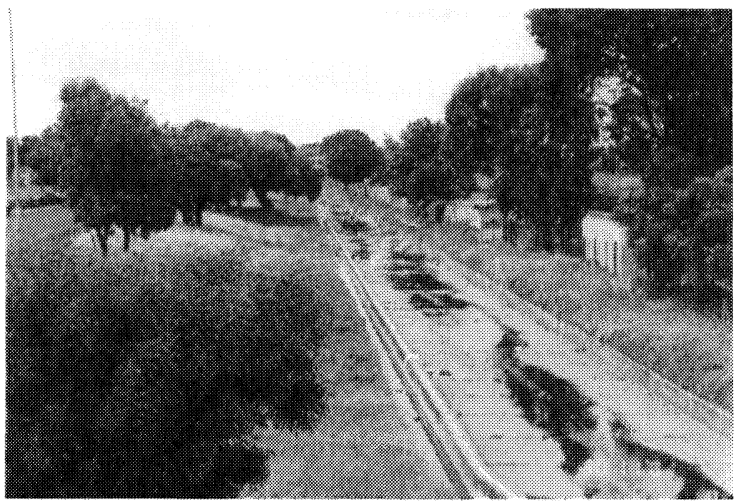

Figure 27.9 Bokmakierie Canal.

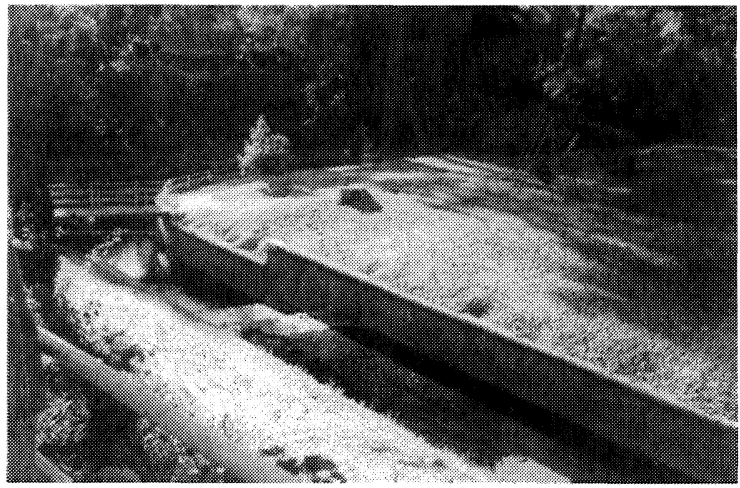

Figure 27.10 Canalised section of Liesbeek River. 
The average $24 \mathrm{~h}$ rainfall depths based on data from rainfall stations in, or in close proximity to, the various sub-catchments are given in Table 27.1. These values illustrate the variation in rainfall over the catchment.

An important aspect arising from Phase II of the study was the need to review the appropriateness of the SA-SCS Type 1 storm for the mountainous area within the Liesbeek River catchment. [The SA-SCS storm distributions (Types 1, 2, 3 and 4) are modified versions of the original $24 \mathrm{~h}$ storm distributions that were developed from rainfall data in the USA for use with the SCS method (Smithers and Schulze, 1987)]. While this part of the catchment experiences high rainfall, this is known to be long-duration, low-intensity rainfall rather than short-duration, high-intensity rainfall. It was evident that the SA-SCS distribution, together with the high $24 \mathrm{~h}$ rainfall, would result in unrealistically high short-duration intensities within the design storm. A subsequent detailed analysis of rainfall recorded at the nearby Newlands and Athlone rainfall stations confirmed this (Smithers and Schulze, May 2002) and a revised storm distribution was developed for this part of the catchment.

Table 27.2 compares the $24 \mathrm{~h}$ and the 15 minute rainfall intensities at the Newlands and Athlone gauges (Arnold, 2003) and illustrates the need for revising the design storm distribution. The Newlands gauge lies within the mountainous part of the Liesbeek catchment, while the Athlone gauge is located away from the mountain to the east of the Liesbeek catchment.

As shown in Table 27.2, there are significant differences between the two stations in terms of $24 \mathrm{~h}$ rainfall with the intensities (and hence total depths) at the Newlands station being up to $200 \%$ greater than those at the Athlone station. There is, however, a closer correlation between the $15 \mathrm{~min}$ intensities, with the Newlands values being on average only $20 \%$ greater than the Athlone values. On the basis of this information and given that the Athlone short duration intensities compare favourably with those generated using the SA-SCS Type 1 distribution, it can be seen that a Type 1 design storm based on the Newlands $24 \mathrm{~h}$ rainfall would include short-duration intensities well in excess of the observed values.

A study of two other gauges confirmed the Phase I finding that the SASCS Type 1 distribution was appropriate for the remainder of the study area.

\subsubsection{Soil Types and Infiltration Parameters}

Details of the major soil types and their runoff potential were obtained from 1:50,000 geological maps and were augmented by detailed information extracted from local geological investigations as well as details obtained from the 
Table 27.1 $24 \mathrm{~h}$ rainfall depths for Salt River sub-catchments.

\begin{tabular}{|c|c|c|c|c|c|c|c|}
\hline \multirow{2}{*}{$\begin{array}{l}\text { Recurrence } \\
\text { Interval } \\
(y)\end{array}$} & \multicolumn{7}{|c|}{24 h Rainfall Depths } \\
\hline & Elsieskraal & $\begin{array}{c}\text { Maitland / } \\
\text { Kensington / } \\
\text { Bokmakierie }\end{array}$ & $\begin{array}{c}\text { Langa / Jakkalsvlei } \\
\qquad / \\
\text { Kalksteenfontein }\end{array}$ & Vygekraal & Blomvlei & $\begin{array}{c}\text { Kromboom / } \\
\text { Black }\end{array}$ & Liesbeek \\
\hline $1: 50$ & $95 \mathrm{~mm}$ & $101 \mathrm{~mm}$ & $111 \mathrm{~mm}$ & $119 \mathrm{~mm}$ & $119 \mathrm{~mm}$ & 120 to $220 \mathrm{~mm}$ & 119 to $250 \mathrm{~mm}$ \\
\hline $1: 100$ & $109 \mathrm{~mm}$ & $117 \mathrm{~mm}$ & $129 \mathrm{~mm}$ & $138 \mathrm{~mm}$ & $138 \mathrm{~mm}$ & 140 to $250 \mathrm{~mm}$ & 134 to $283 \mathrm{~mm}$ \\
\hline
\end{tabular}

Table 27.2 Comparison of rainfall intensities - Liesbeck River subcatchment .

\begin{tabular}{|c|c|c|c|c|c|}
\hline \multirow{2}{*}{ Station } & \multicolumn{5}{|c|}{ Recurrence Interval } \\
\hline & $1: 2 y$ & $1: 5 \mathrm{y}$ & $1: 10 \mathrm{y}$ & $1: 20 \mathrm{y}$ & $1: 50 \mathrm{y}$ \\
\hline \multicolumn{6}{|c|}{$24 \mathrm{~h}$ Rainfall Intensity (mm/hr) } \\
\hline Newlands & 4.9 & 6.7 & 8.0 & 9.2 & 11.0 \\
\hline Athlone & 2.0 & 2.5 & 2.8 & 3.1 & 3.5 \\
\hline \multicolumn{6}{|c|}{$15 \mathrm{~min}$ Rainfall Intensity $(\mathrm{mm} / \mathrm{hr})$} \\
\hline Newlands & 52.8 & 62.0 & 68.8 & 76.8 & 84.8 \\
\hline Athlone & 43.6 & 52.4 & 59.6 & 66.4 & 76.0 \\
\hline
\end{tabular}


Agricultural Research Council, Institute for Soil, Climate and Water.

The distribution across the catchment is essentially sandstone and scree on the slopes of Table Mountain with loamy soils of granitic origin at the foot of the mountain. Shale and residual soils are found in the Tygerberg Hills to the north-east with Cape Flats sands in the central area of the catchment. Appropriate infiltration rates for the various sub-catchments were assigned on the basis of this information.

\subsection{Configuration of Catchment Models}

\subsubsection{Pipe and Culvert Network}

Prior to commencing Phase II of the study, the City of Cape Town initiated a Services Data Capture Project, which was undertaken by a number of GIS consultants. The output from the data capture project (DCP) provided details of the pipe and culvert network for the Visual SWMM models.

On receiving the DCP ARCVIEW databases, it was found that considerable additional effort was required to translate these into sub-catchment datasets in a format suitable for importing into Visual SWMM. This involved extracting details of stormwater pipes, culverts and manholes together with their associated attributes such as coordinates, invert levels, ground levels and pipe and culvert sizes. The process also included the subsequent infilling of missing data and the manipulation of the data using spreadsheets.

Although there were shortcomings in the DCP databases, in terms of missing data, it was also true that in some areas, the database was too detailed for modeling purposes. This occurred in areas where there were a large number of manholes with pipe lengths as short as $1 \mathrm{~m}$ between them. This required rationalising of the data by way of omitting manholes and stringing together a number of pipes to form longer conduits. This was necessary for improving the stability of the model runs and for reducing model run times. However, despite rationalising the Elsieskraal model, the final version still included 3,250 conduits that, in retrospect, could have been rationalised even further. Initial run times for the Elsieskraal model were in the region of eight hours but rationalising the model and optimising the EXTRAN simulation time step eventually reduced the run times to just under 60 minutes. Figure 27.11 shows the layout of the drainage system as modeled in the Elsieskraal River sub-catchment. 


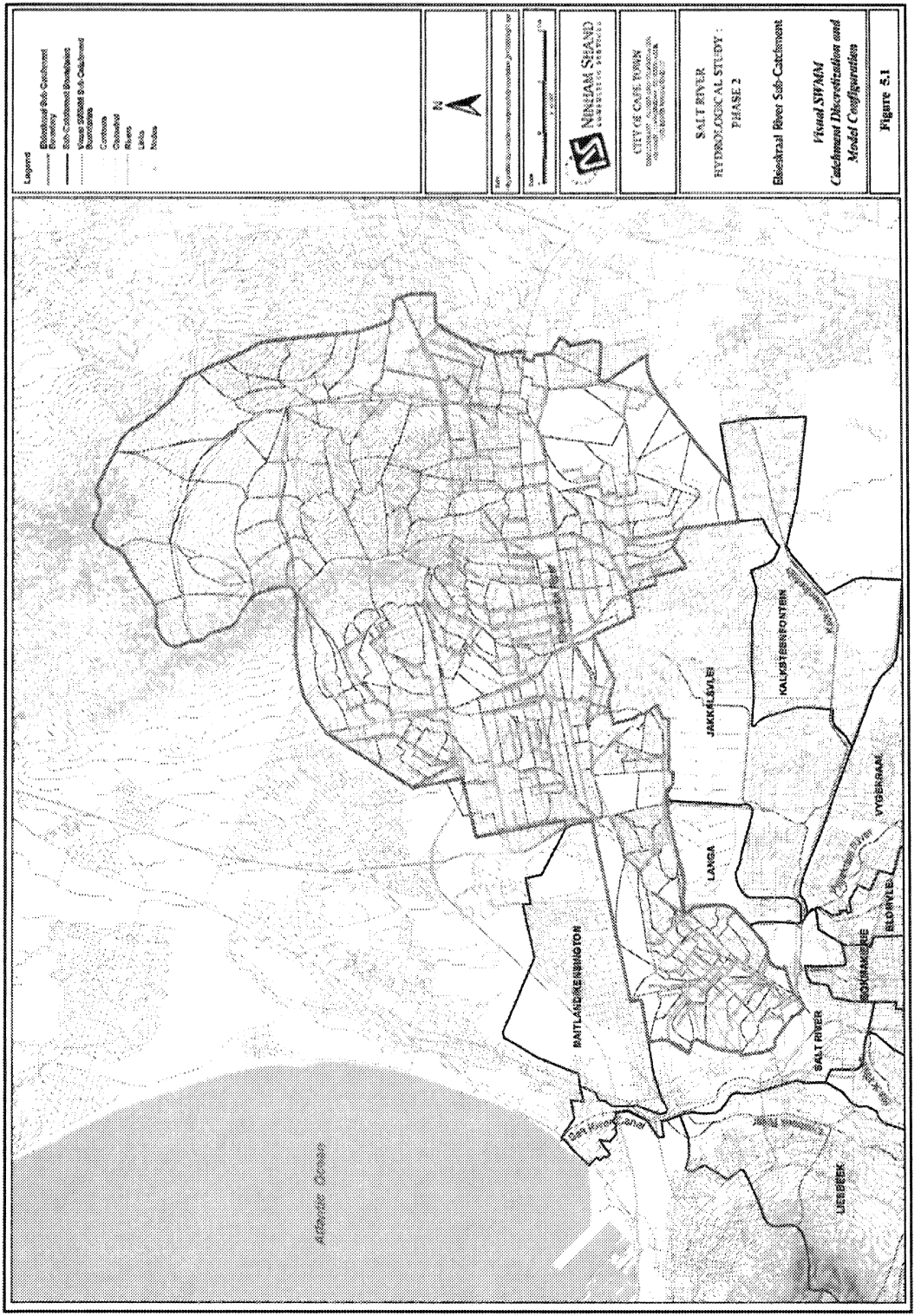

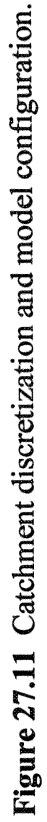




\subsubsection{Natural Channels, Canals and Overland Drainage Routes}

Details of the natural channels, canals and overland drainage routes (the major system conduits) had to be sourced and manually entered into the models. Profiles of natural channels were extracted from contour drawings. In the case of constructed canals, details were either obtained from as-built drawings or field surveys. Overland drainage routes, for flows in excess of the underground drainage system, were determined from contour drawings. Cross-section profiles for the overland drainage routes were dimensioned according to road profiles along the identified routes.

\subsubsection{Formal and Informal Stormwater Retention}

Stormwater retention ponds within the sub-catchments were included in the Visual SWMM models. However, the fact that many of these had been designed for 1:5 to $1: 20 \mathrm{y}$ storm events meant that they had little effect on downstream flow rates when considering the 1:50 y and particularly the 1:100 y events. In many instances, informal retention and attenuation of flood peaks has a greater effect than the formal retention. This informal attenuation typically occurs during 1:50 and 1:100 y events at locations where road and railway embankments form barriers to overland flow and pipes or culverts limit flow through these barriers. Informal retention and detention of runoff in the low-lying, undrained areas of the Cape Flats also has a significant effect on runoff that ultimately reaches the Salt River Canal. The consultants generally relied on their knowledge of the sub-catchments and on information from the city regarding historic flooding in order to identify these areas.

Both formal and informal retention was included in the Visual SWMM models using the ponding allowed option at appropriate nodes. The storage capacity at these nodes was modeled using either an approximate power function relationship or, where more specific information was available, by way of user defined depth/area relationships.

\subsubsection{Land Use and Future Development}

Future changes in land use, which would impact on stormwater runoff, needed to be identified and allowed for in the catchments models. Seeing that the catchment is already highly urbanised, it was found that most of the change would be in terms of densification of existing developments rather than changes from undeveloped to developed. 


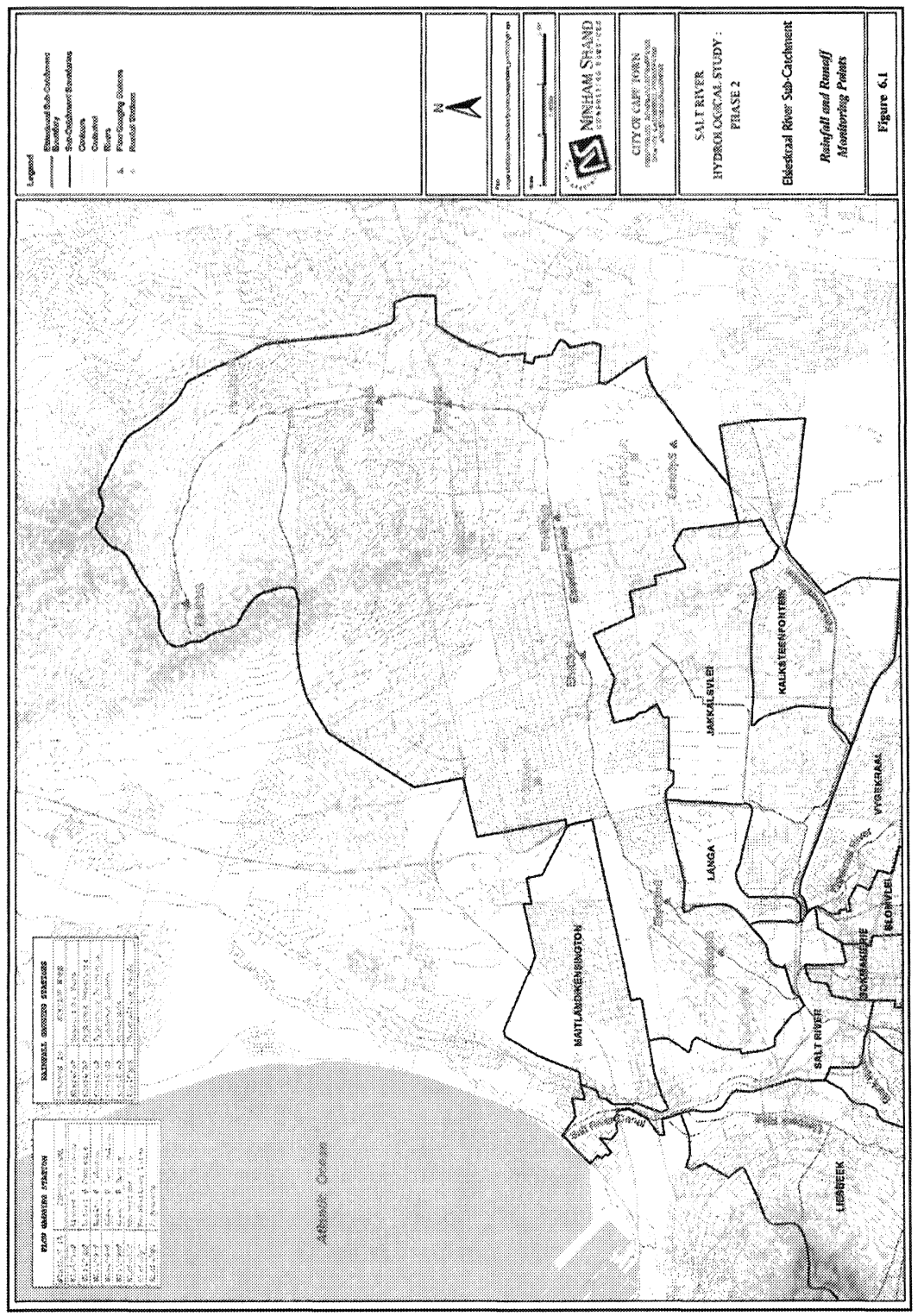

 


\subsection{Calibration of Visual SWMM Catchment Models}

There is a lack of recorded rainfall and runoff data throughout the Salt River catchment with the exception of the Elsieskraal sub-catchment where a rainfall and runoff monitoring system has been in place since 1985. This meant that, of the twelve sub-catchment models, only the Elsieskraal model could be calibrated. The locations of the recording stations in the Elsieskraal subcatchment are shown in Figure 27.12

The data used for calibrating the Elsieskraal model was recorded during one of the most severe storms that has occurred over the Elsieskraal subcatchment since 1985. This storm occurred on 10/11 April 1993 when rain fell almost continuously over a $48 \mathrm{~h}$ period. The most intense period of the storm was between 15:00 and 19:00 on Sunday, 11 April and several areas in the catchment were flooded. The daily rainfall recorded at the six gauges within the catchment for the period Friday, 9 April to Tuesday, 13 April is given in Table 27.3.

It can be seen that the heaviest rainfall occurred on Sunday, 11 April 1993. Four of the six gauges exceeded the 1:50 y 1-d rainfall (i.e. $86 \mathrm{~mm}$ ) while two of the gauges (Bellville and Goodwood) exceeded the 1:100 y 1-d rainfall (i.e. greater than $98 \mathrm{~mm}$ ). Despite the heavy, long duration rain, a detailed analysis of the storm data revealed that shorter duration rainfall (up to $1 \mathrm{~h}$ ) generally had recurrence intervals of less than 1:10 y (Ninham Shand, 1993). Because of the severity of this storm, it was considered suitable for calibration purposes and runoff simulated using the Visual SWMM model was compared with the recorded flow rates at the Tygerberg and Pinelands flow gauges.

The best correlation between recorded and simulated flows was eventually obtained using infiltration rates applicable to a saturated catchment together with depression storages of zero in the upper catchment. These values were considered as being justifiable given the high antecedent rainfall. The recorded and simulated hydrographs at the two monitoring stations are compared in Figures 27.13 and 27.14.

In the case of the remaining Salt River sub-catchments, verification of the models was limited to comparing Visual SWMM results with those determined using alternative methods (e.g. the Rational and SCS methods). The fact that calibration of the remaining Salt River sub-catchments could not be undertaken is seen as a significant limitation of the study. This has been acknowledged and accepted by CSRM with the result that the floodlines determined as part of this study are referred to as provisional floodlines. 
Table 27.3 Total daily rainfall - 9 April to 13 April 1993.

\begin{tabular}{ccccccc}
\hline & \multicolumn{5}{c}{ Recorded Rainfall (mm) } \\
\cline { 2 - 7 } Day & $\begin{array}{c}\text { R01 } \\
\text { (Maastricht) }\end{array}$ & $\begin{array}{c}\text { R02 } \\
\text { (Durbanville) }\end{array}$ & $\begin{array}{c}\text { R03 } \\
\text { (Tygerberg) }\end{array}$ & $\begin{array}{c}\text { R04 } \\
\text { (Bellville) }\end{array}$ & $\begin{array}{c}\text { R05 } \\
\text { (Goodwood) }\end{array}$ & $\begin{array}{c}\text { R06 } \\
\text { (Pinelands) }\end{array}$ \\
\cline { 2 - 7 } Fri, 9 Apr 1993 & 1.0 & 0.8 & 1.6 & 2.2 & 2.0 & 1.2 \\
Sat, 10 Apr 1993 & 9.8 & 5.4 & 7.4 & 7.0 & 12.8 & 11.2 \\
Sun, 11 Apr 1993 & 66.4 & 92.0 & 91.8 & 100.8 & 124.8 & 75.0 \\
Mon, 12 Apr 1993 & 21.0 & 30.6 & 27.2 & 32.2 & 33.2 & 21.8 \\
Tues, 13 Apr 1993 & 2.4 & 0.4 & 0.2 & 1.0 & 2.2 & 1.6 \\
\hline
\end{tabular}

Table 27.4 Peak flow rates from Salt River sub-catchments.

\begin{tabular}{|c|c|c|c|c|c|c|c|c|}
\hline \multirow[b]{2}{*}{$\begin{array}{l}\text { Recurrence } \\
\text { Interval } \\
(y)\end{array}$} & \multicolumn{8}{|c|}{ Peak Flow Rate at Sub-catchment Outfalls } \\
\hline & $\begin{array}{l}\text { Elsieskraal } \\
\left(92.0 \mathrm{~km}^{2}\right)\end{array}$ & $\begin{array}{c}\text { Maitland / } \\
\text { Kensington / } \\
\left(9.6 \mathrm{~km}^{2}\right)\end{array}$ & $\begin{array}{c}\text { Langa / } \\
\text { Jakkalsvlei / } \\
\text { Kalksteenfontein } \\
\left(31.7 \mathrm{~km}^{2}\right)\end{array}$ & $\begin{array}{l}\text { Vygekraal } \\
\left(16.7 \mathrm{~km}^{2}\right)\end{array}$ & $\begin{array}{l}\text { Blomvlei } \\
\left(11.4 \mathrm{~km}^{2}\right)\end{array}$ & $\begin{array}{c}\text { Bokmakierie } \\
\left(4.2 \mathrm{~km}^{2}\right)\end{array}$ & $\begin{array}{c}\text { Kromboom / } \\
\text { Black } \\
\left(14.1 \mathrm{~km}^{2}\right)\end{array}$ & $\begin{array}{l}\text { Liesbeek } \\
\left(26.0 \mathrm{~km}^{2}\right)\end{array}$ \\
\hline $1: 50$ & $96 \mathrm{~m}^{3} / \mathrm{s}$ & $15 \mathrm{~m}^{3} / \mathrm{s}$ & $41 \mathrm{~m}^{3} / \mathrm{s}$ & $33 \mathrm{~m}^{3} / \mathrm{s}$ & $12 \mathrm{~m}^{3} / \mathrm{s}$ & $6 \mathrm{~m}^{3} / \mathrm{s}$ & $71 \mathrm{~m}^{3} / \mathrm{s}$ & $126 \mathrm{~m}^{3} / \mathrm{s}$ \\
\hline $1: 100$ & $110 \mathrm{~m}^{3} / \mathrm{s}$ & $16 \mathrm{~m}^{3} / \mathrm{s}$ & $68 \mathrm{~m}^{3} / \mathrm{s}$ & $40 \mathrm{~m}^{3} / \mathrm{s}$ & $14 \mathrm{~m}^{3} / \mathrm{s}$ & $6 \mathrm{~m}^{3} / \mathrm{s}$ & $74 \mathrm{~m}^{3} / \mathrm{s}$ & $161 \mathrm{~m}^{3} / \mathrm{s}$ \\
\hline
\end{tabular}




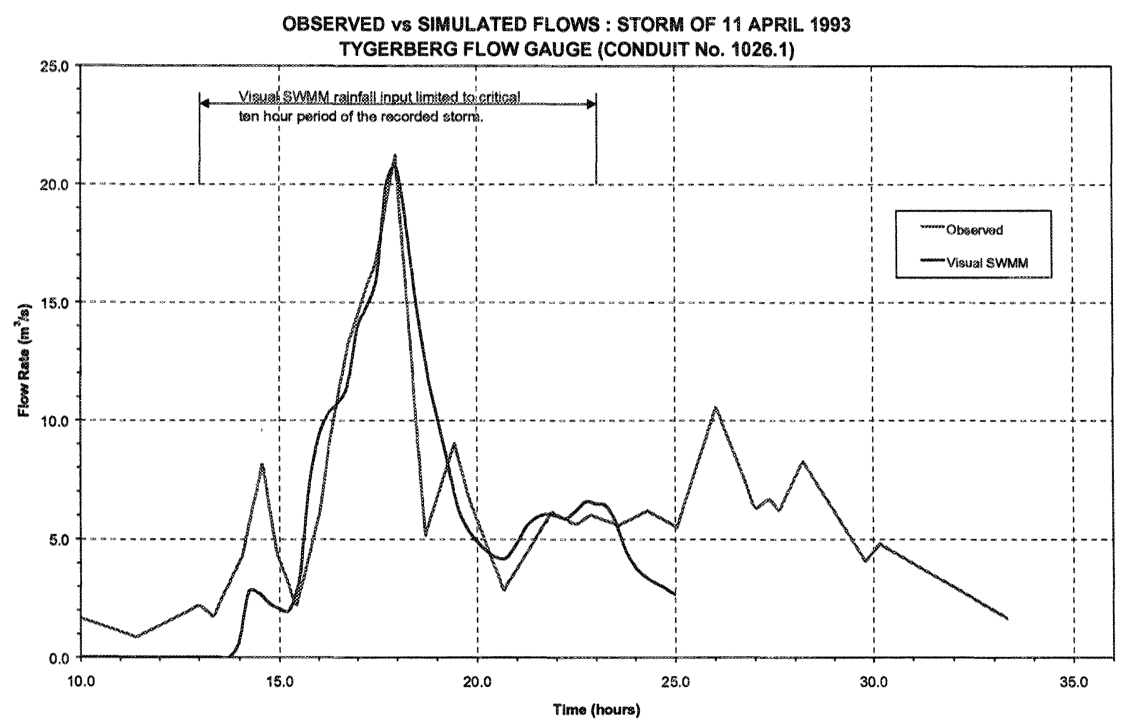

Figure 27.13 Model calibration - Tygerberg Gauge.

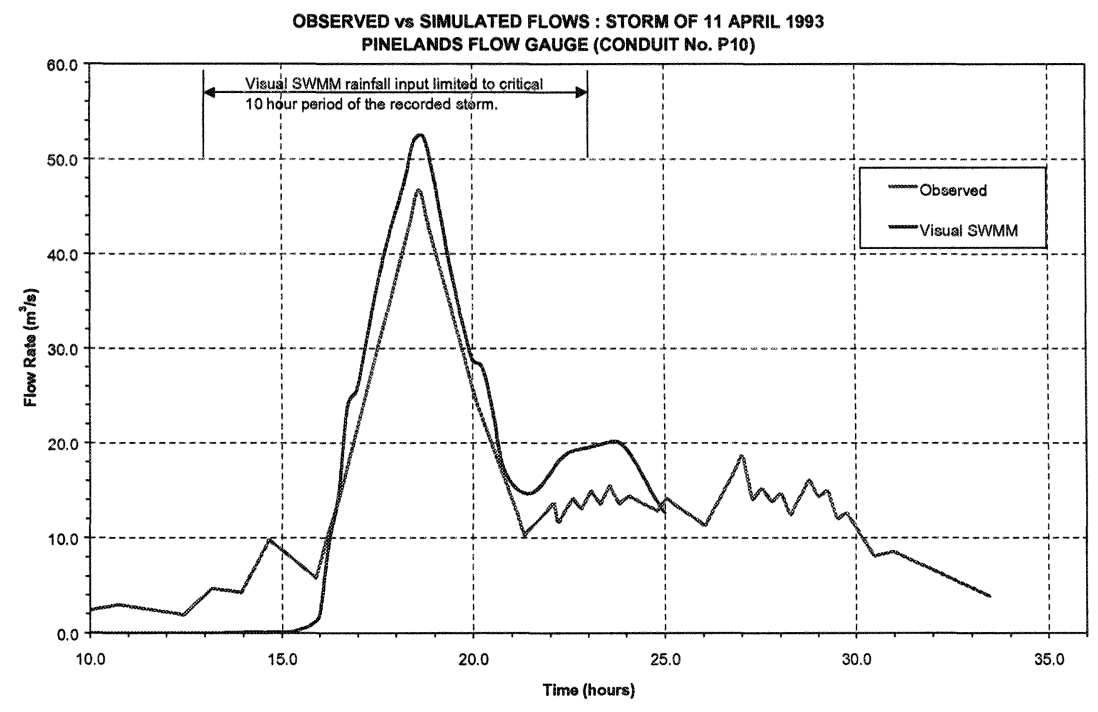

Figure 27.14 Model calibration - Pinelands Gauge. 


\subsection{Simulation of 1:50 and 1:100 y Flow Rates and Outfall Hydrographs}

The simulated 1:50 and 1:100 y peak flow rates from the various subcatchments are given in Table 27.4.

Although the Elsieskraal sub-catchment is more than three times larger than the Liesbeek sub-catchment, the Liesbeek has the higher flow rate. This is due to the higher rainfall and the steepness of the topography which results in relatively little formal or informal attenuation of flood peaks. By contrast, the lower areas of the Elsieskraal sub-catchment are flat and there are significant restrictions on runoff entering the Elsieskraal Canal. A similar comparison can be made between the Kromboom/Black River sub-catchment and the Langa, Jakkalsvlei and Kalksteenfontein sub-catchment where, although the latter is a larger sub-catchment, runoff is less due to informal retention in low-lying areas.

The 1:50 y and 1:100 y outfall hydrographs for the Salt River subcatchments are shown in Figures 27.15 and 27.16 respectively.

In order to take the effect of downstream water levels into account, the outfall hydrographs were determined on an iterative basis. Initial runoff simulations were carried out using fixed downstream water levels taken as the

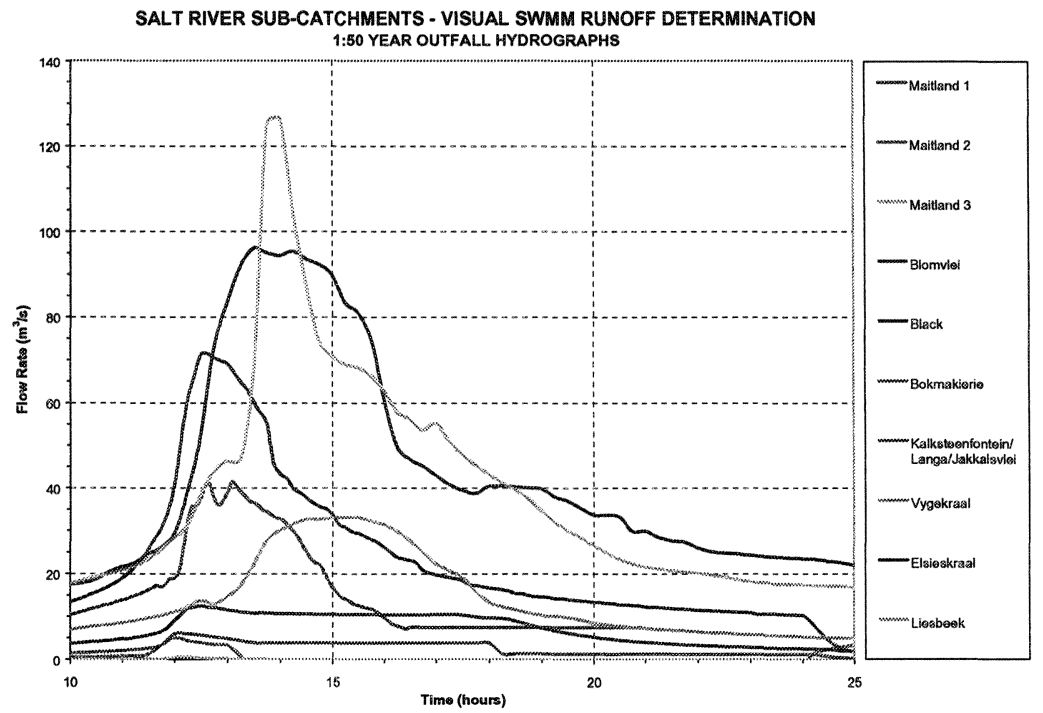

Figure 27.15 Salt River sub-catchments - runoff determination - 1:50 y outfall hydrographs. 


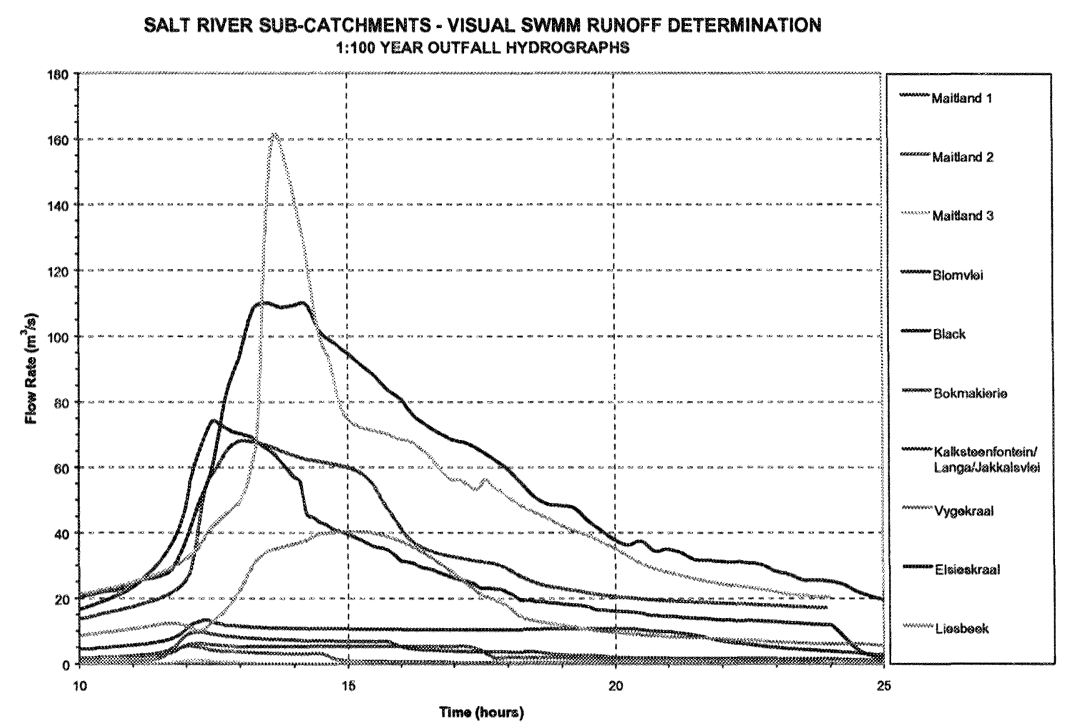

Figure 27.16 Salt River sub-catchments - runoff determination - 1:100 y outfall hydrographs.

bankfull level. These outfall hydrographs were then used as inflow hydrographs for the Salt River model (described in Section 27.8). The Salt River model was then run and stage histories were determined at each inflow node. These stage histories were then used as the downstream boundary conditions for the subcatchment models and revised outfall hydrographs were simulated. The revised hydrographs were compared with the initial hydrographs and a second iteration of river model and sub-catchment model simulations were performed. The transfer of data to and from the river and sub-catchment models was done by importing and exporting.xpx format files containing the hydrographs and stage histories.

At an early stage in the project, consideration had been given to combining the various sub-catchment models into a single model for analysing flow and flood levels in the Salt River. This would have obviated the need for transferring hydrographs and stage histories between consultants. However, the size of the individual sub-catchment models and long run-times meant that the combined model would have been cumbersome and time-consuming to use. It was therefore accepted that it would be more efficient for the consultants to run their individual models and to provide input to the river model by way of exported hydrographs. The drawback of this approach is that the analysis of Phase III 
remedial work scenarios may become a protracted process with up to seven consultants having to rerun models depending on the various options to be investigated.

\subsection{Floodline Determination}

After completion of the hydrological studies, floodlines were determined for the Liesbeek, Elsieskraal and Vygekraal/Black/Salt Rivers (refer Figure 27.17). In the case of the Liesbeek River, this involved analysing the $6 \mathrm{~km}$ stretch of river from Paradise Road through to the confluence with the Black River. In the case of the Elsieskraal River, the $3 \mathrm{~km}$ stretch of river through Pinelands was analysed. In the case of the Vygekraal/Black and Salt Rivers, the $8.3 \mathrm{~km}$ stretch of river from just downstream of the Vygekraal/Blomvlei confluence through to the mouth was analysed. In the context of the greater Salt River Catchment, CSRM considered these rivers to be the most significant in terms of flooding. Floodlines for the remaining rivers of the catchment will be determined in due course.

\subsubsection{River Models}

The Liesbeek and Elsieskraal River floodlines were determined using the respective Visual SWMM models while the Vygekraal/Black/SaltRiver floodlines were determined using both a Visual SWMM river model and a HEC-RAS river model.

The reasons for using the two models for the Vygekraal/Black/Salt River analysis were:

- the significant attenuation of flood peaks due to large floodplain areas which was best modeled using Visual SWMM, and

- the large number of culvert and bridge structures (35 in the 8.3 $\mathrm{km}$ stretch of river) which were best modeled using HECRAS.

Culverts and bridges have been modeled satisfactorily by others using SWMM-EXTRAN (Schmidt, 2003). However, the decision to proceed with the two separate models was based on budget constraints and limited previous experience in using SWMM-EXTRAN for this purpose.

Initial simulations were therefore carried out using Visual SWMM to determine the effects of floodplain attenuation with the attenuated flood peaks then being used as input data for the HEC-RAS model for determining the final water profiles taking the effect of bridges and culverts into account. 


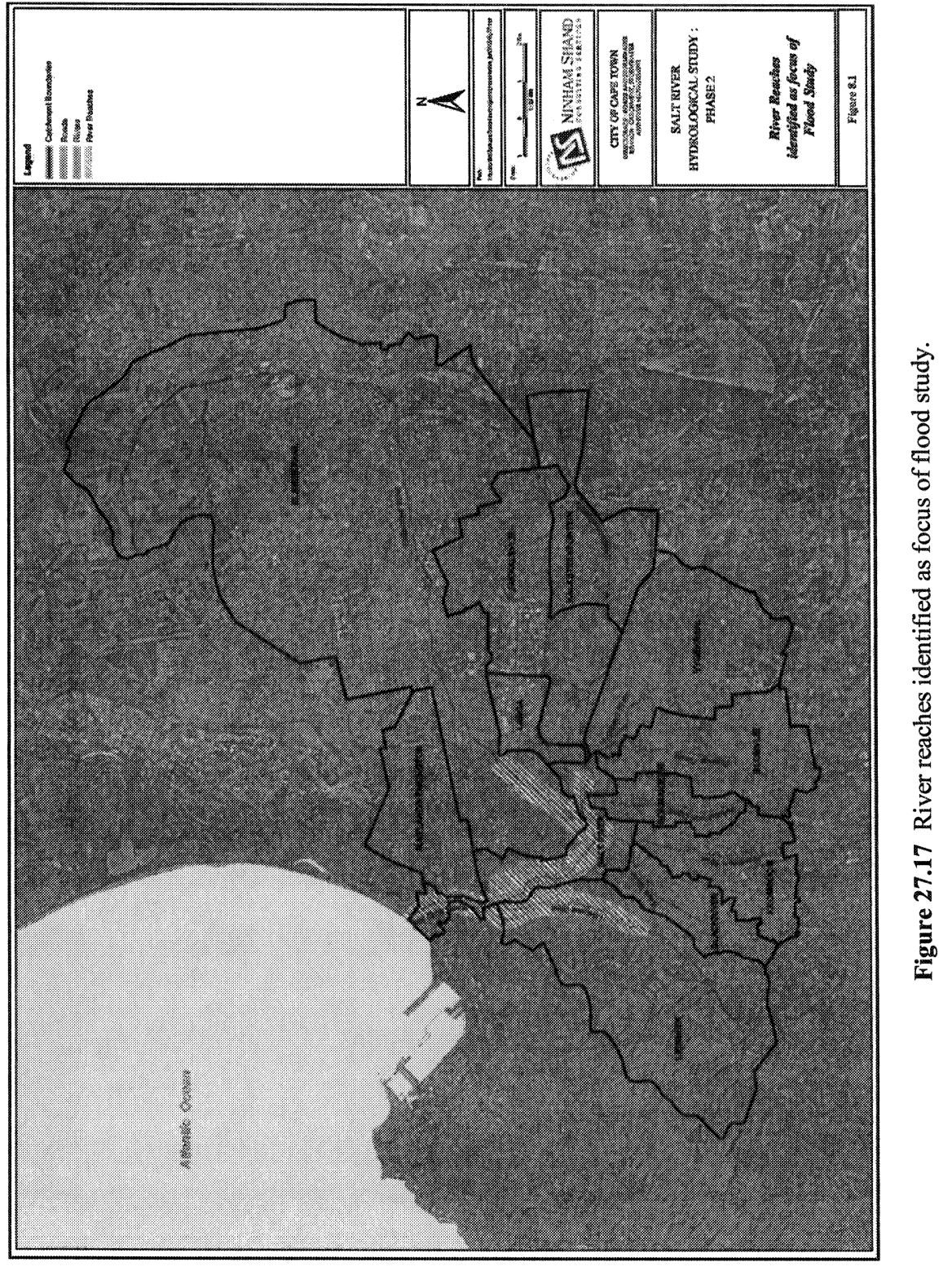


The effect of tidal conditions was taken into account by assuming a worst case scenario where the flood peak at the mouth of the Salt River was assumed to be coincident with a Mean High Water Spring Tide plus a storm surge of $0.3 \mathrm{~m}$ in Table Bay.

\subsubsection{Verification of Salt River Model}

On 29 August 2001 a storm over most of the catchment resulted in overtopping of the lower reach of the Liesbeek River Canal as well as overtopping of the main channel at the confluence of the Liesbeek and Black Rivers (Figure 27.3). Although there are no flow gauging stations in this vicinity, the event was recorded by means of a series of photographs that were taken at several of the bridges crossing the Salt River Canal. Fortuitously, the photographs were taken at the time of peak flow, making it possible to estimate the maximum water levels and hence peak flow rates at the bridge sites. This information together with recorded rainfall data was used to carry out a coarse verification of the subcatchment and river models.

Rainfall recorded at gauges throughout the catchment was sourced and used to simulate runoff hydrographs from the various sub-catchments (refer Figures 27.18 and 27.19). These hydrographs were then used as inflow hydrographs for the Salt River model and the simulated water levels at bridge sites were compared with the photographic records (e.g. Figure 27.4, showing the water lapping the underside of the Voortrekker Bridge). It was found that there was good correlation between the observed and simulated flood levels which provided some confidence in the catchment and river models. However, it was not possible to verify the correctness of the contributions from the individual sub-catchments due to the lack of observations and recorded flow data further upstream in the system.

\subsubsection{Results of Floodline Analyses}

The results of the floodline analyses were presented to the client as a set A0 floodline drawings (see example Figure 27.20). These drawings were also submitted as a series of ARCVIEW shape files with attribute data linked to each of the cross-section positions. The attribute data included details of flow rates, water surface levels, energy levels and channel and floodplain velocities.

The analysis of the Elsieskraal Canal and the Vygekraal, Black and Salt Rivers confirmed that widespread flooding of residential, commercial and industrial properties could be expected to occur during 1:50 y and 1:100 y flood 


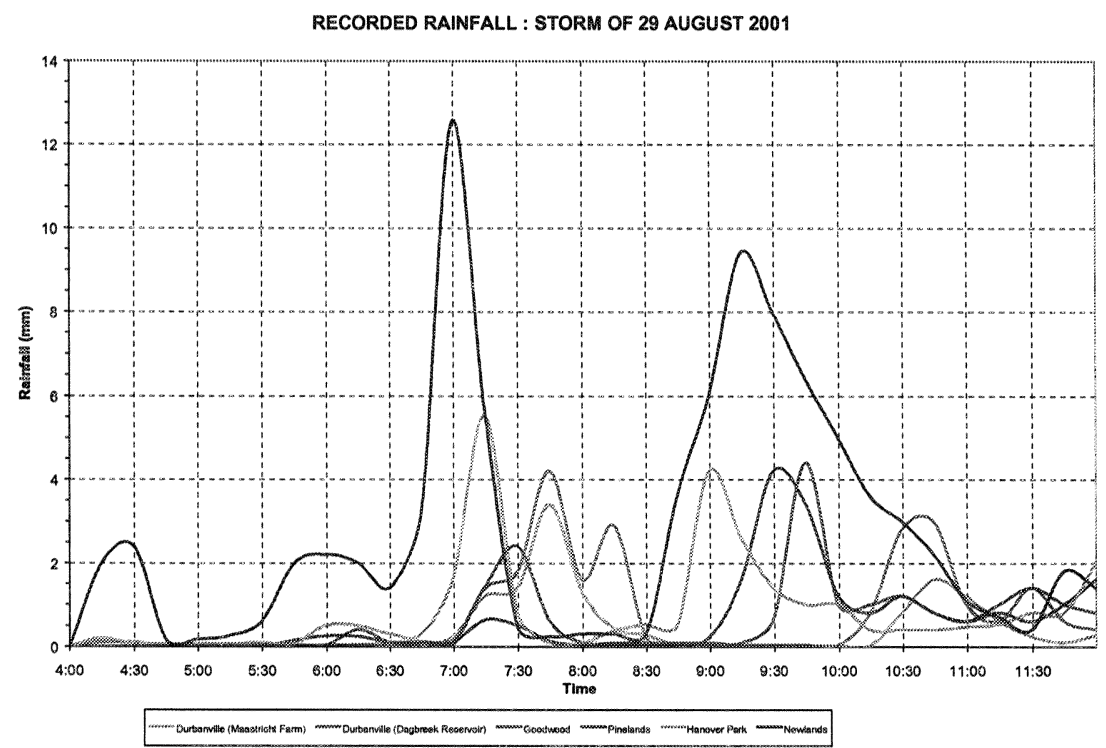

Figure 27.18 Salt River Visual SWMM / HECRAS river model verification recorded rainfall - storm of 29 August 2003.

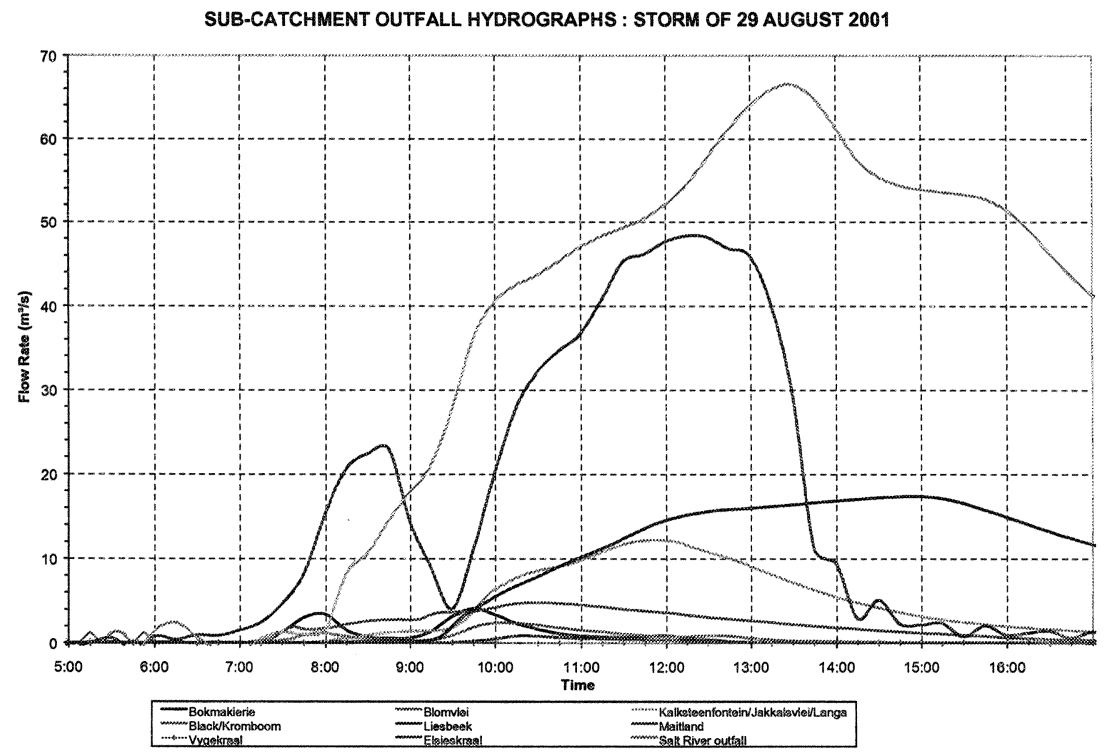

Figure 27.19 Salt River Visual SWMM / HECRAS river model verification sub-catchment outfall hydrographs - storm of 29 August 2003. 


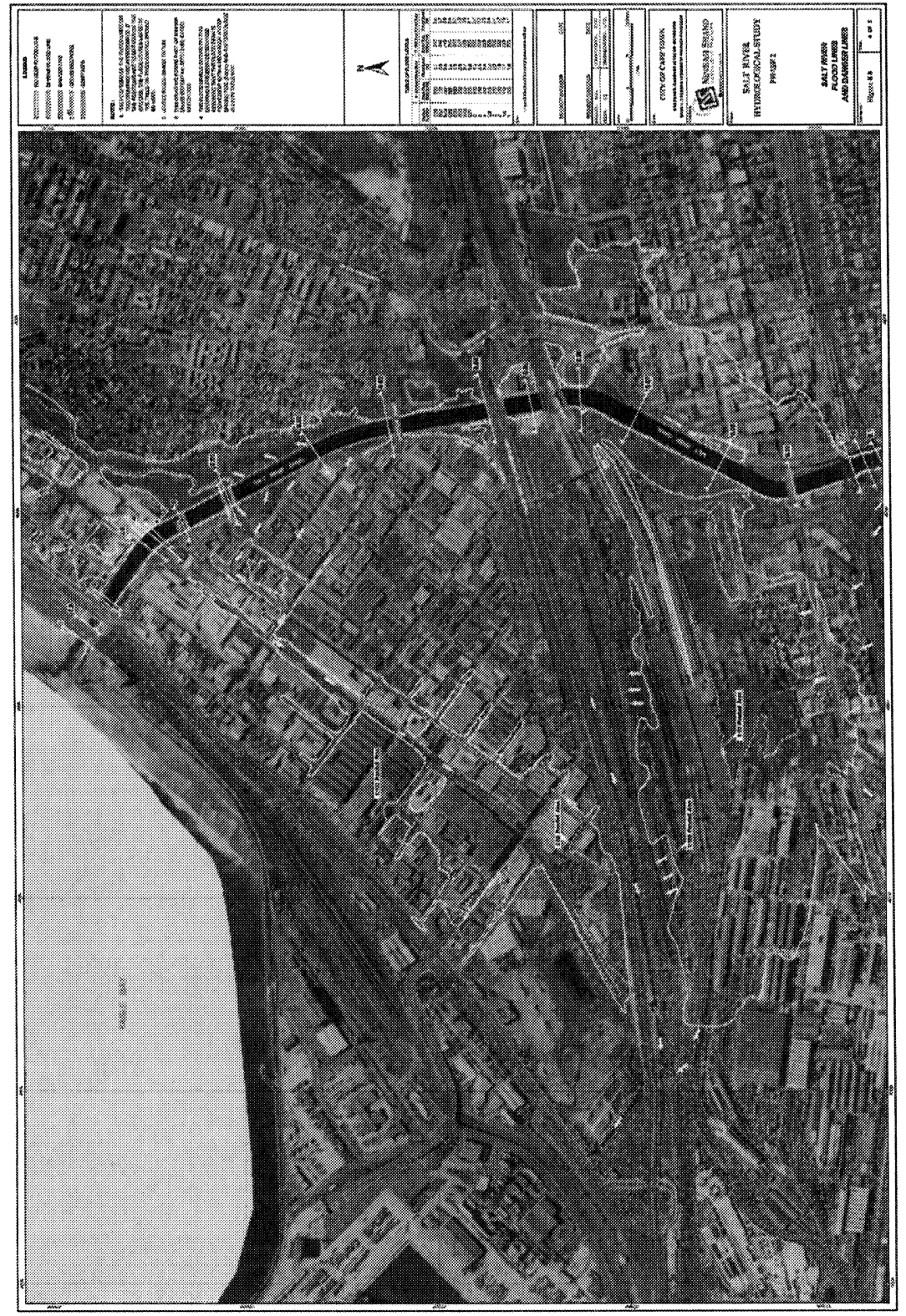

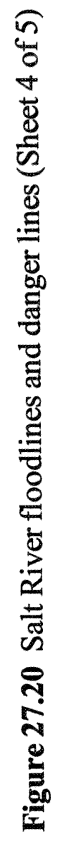


events. It was also found that important road and rail routes linking the city centre to the suburbs would be severed at various locations where these cross the rivers. This would result in major disruption of the movement of commuters into and out of the city centre. It would also inhibit the movement of emergency and rescue vehicles. The situation was found to be particularly onerous in the case of the 1:100 y flood event.

Apart from local flooding in the immediate vicinity of the main rivers, it was also established that floodwaters would exit the main river channel at the confluence of the Liesbeek and Black Rivers and would flow overland through the Salt River railway yard towards Voortrekker Road. Indications are that in the event of this happening, floodwater would flow in a northerly direction over Voortrekker Road towards a low point in the railway sidings between Voortrekker Road and the N1 freeway. This water would eventually be intercepted by the old Salt River Canal (which runs in an east/west direction immediately south of the N1) and would be discharged into Table Bay.

Reference to a map of early Cape Town (circa 1910 - refer Figure 27.21) and literature on the rivers of early Cape Town (SESA, 1973 and Pickard, 1968) revealed that the anticipated overland flow path follows the route of the original watercourse prior it being deviated along the route of the concrete lined canal. The flooding that is predicted adjacent to the Salt River Canal would therefore be the result of flood waters reverting to the line of the original watercourse and ponding in areas previously occupied by marshes and vleis.

\subsection{Conclusions}

Despite the fact that the floodlines presented in this study are considered to be provisional, they do provide an indication of the extent of flooding that can be expected during severe storm events. The information provided highlights the potential flooding of residential areas where the need for and viability of flood warning systems and/or emergency evacuation plans should be investigated.

Apart from highlighting areas that would be subject to flooding, the information provided should prove valuable to emergency services and disaster management units for purposes of planning and preparedness in the event of major floods.

While every effort was made to ensure the accuracy of the results of the study within the bounds of the limited data available for calibration and verification of the models, further calibration and verification is necessary to increase the level of confidence in the results. Recording of rainfall and runoff 


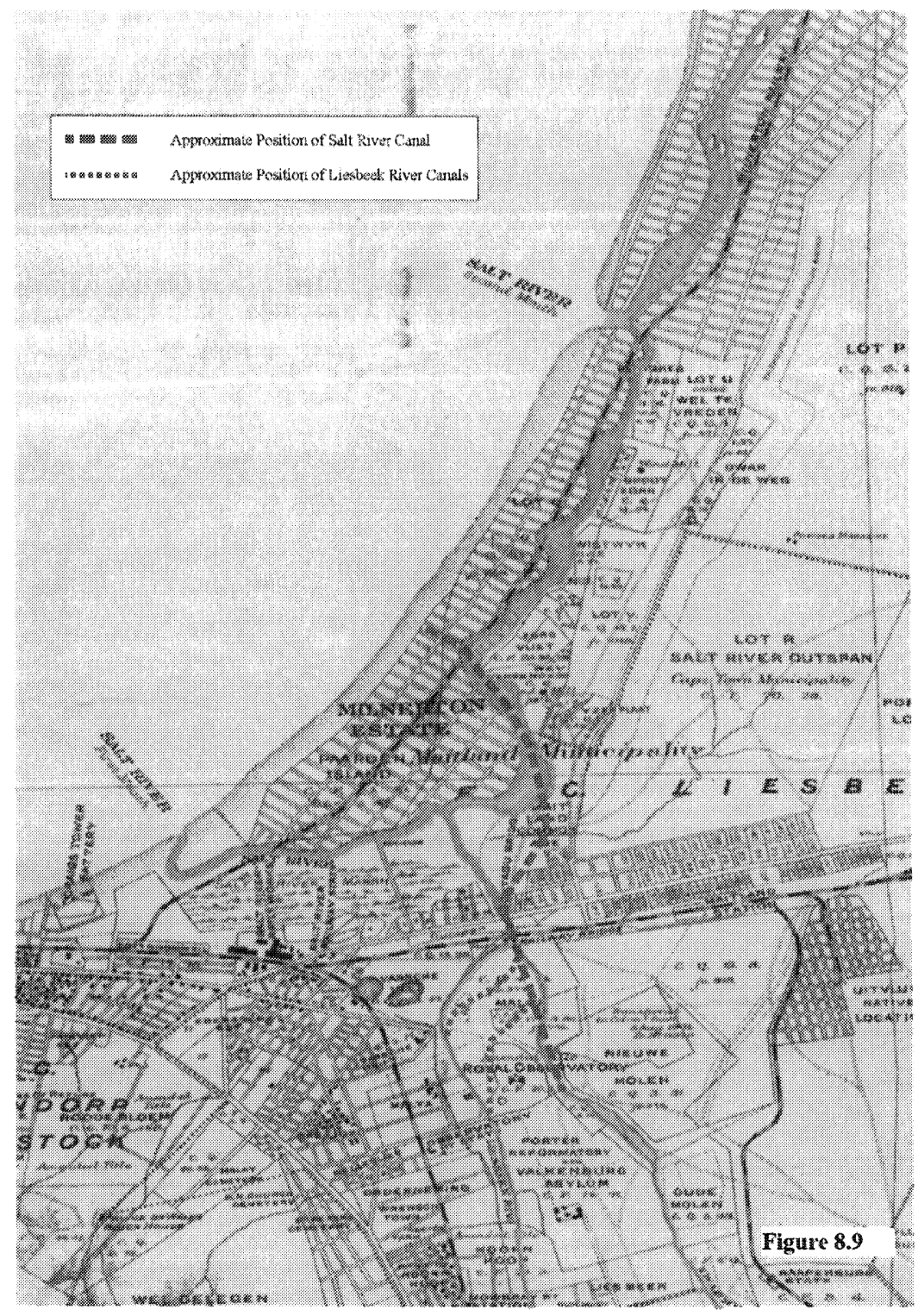

Figure 27.21 Historical perspective - map of Cape Town (circa 1910).

at the existing and recently installed monitoring stations throughout the catchment is therefore considered to be essential. 


\subsection{Recommendations}

The following recommendations were made to assist the city in defining a way forward for the next phase of the Salt River Hydrological Study:

- The results of the study should be presented to the City Council so that councillors are informed as to the risk of flooding that the city is exposed to.

- Information on potential flooding should be made available to the city's Disaster Management Services for purposes of planning and preparedness in the event of major flood events.

- Investigations should be carried out into the need for and viability of implementing flood warning systems and/or emergency evacuation plans in residential areas that are subject to flooding.

- Investigations should be carried out to determine ways of alleviating flooding along the main rivers of the Salt River Catchment. These investigations could include the options of doing nothing, of widening the Salt River Canal, of constructing additional/alternative drainage routes along identified paths of overland flow, of providing upstream flood attenuation facilities or of raising and/or constructing embankments along the canal.

- Cost/benefit analyses, which include the cost of flood damage, need to be undertaken to enable identification of the most appropriate remedial/ameliorative works.

- Calibration and verification of the catchment models should be undertaken immediately after suitable rainfall and runoff data becomes available. This would improve the level of confidence in the results of the study and could impact on the direction in which future studies may go.

- Consideration should be given to developing a less cumbersome, less detailed "lumped" catchment model for use in investigating alternative measures for alleviating flooding.

- The contribution of runoff from the catchment draining directly to the old Salt River Canal should be investigated to confirm that this canal has sufficient capacity to cater for additional overland flow from the Salt River Canal.

- Local surveys should be undertaken at critical locations along the Salt River Canal where floodwaters have been shown to exit the canal and flood adjacent areas. Local surveys of canal bed levels should also be undertaken to clarify anomalies in certain areas. 
- The possible interaction between the Salt and Diep River systems during significant flood events should be investigated in more detail.

\subsection{Lessons Learned from the Salt River Hydrological Study}

The following points are a combination of modeling and management issues. Some of them may appear obvious but have been reinforced during the Salt River Hydrological Study:

- When modeling large catchments, the objective of the study needs to be carefully considered from the start and an appropriate level of detail for the models should be discussed and agreed with the Client. In the case of the Salt River Study, modeling was possibly carried out at too detailed a level as a result of the availability of a detailed database.

- Following from the above point, there needs to be an awareness of the quality and completeness of the database that is to be used. The availability of a database does not necessarily mean that the task of configuring a model is going to be easier or quicker. In the case of the Salt River Study, the effort required to convert the Data Capture Project database into functioning Visual SWMM models was severely underestimated.

- If at all possible, a modeler's introduction to SWMM should be by way of small, manageable models. To start out with a model comprising 3,200+ nodes and conduits, with model run times of eight hours and with instabilities in the results throughout the model is intimidating and can wear down even the most resolute modeler.

- The Numerical Model Judgement Section in the SWMM output file was found to be extremely useful in locating problem conduits and for homing in on an appropriate EXTRAN simulation time step.

- On a general note, it was found that management of a multiconsultant project is time consuming and that the required management input is easily underestimated. In the case of the Salt River Study, additional management effort was expended due to 
problems with the database and the fact that all of the consultants were new to Visual SWMM. The lack of experience in using SWMM impacted on the efficiency of work undertaken by all of the consultants.

\section{Acknowledgments}

The authors would like to express their gratitude to the following persons for their valuable contributions during the course of the project:

Mr Mark Obree, Mr R Arnold and Mr P Guise of the City of Cape Town; Members of staff in the Stormwater Drainage Branches of the Tygerberg, South Peninsula and Cape Town Administrations who assisted with the gathering of drainage system data;the Phase I Study Team comprising members of staff at Sigma Beta, SRK and Ninham Shand; the Phase II Study Team - comprising members of staff at Africon, BKS, De Villiers Sheard, Arcus Gibb, KFD Wilkinson, iCE and Ninham Shand; DrR Berg-Initial Project Leader for Ninham Shand, who carried out most of the Phase I work and the Phase II work associated with GIS and database manipulations and who also provided advice and assistance after relocating to Australia mid-way through the project.

\section{References}

Adamson P T, 1983. Southern African Storm Rainfall. Department of Environmental Affairs. Technical Report TR 102.

Africon, 2001. Salt River Hydrological Study - Phase II. Bokmakierie and Maitland/ Kensington Catchments. Report compiled for City of Cape Town, Catchment, Stormwater and River Management Branch.

Alexander W J, 1991. Flood Hydrology for Southern Africa. Department of Civil Engineering, University of Pretoria, 1991.

Arnold R, 2003. Stormwater Design : A Southern Perspective. Lecture Notes - Short Course on Floods and Stormwater. Department of Engineering, University of Stellenbosch, South Africa.

Arcus Gibb, 2001. Salt River Hydrological Study - Phase II. Vygekraal River Hydrological Study. Report compiled for City of Cape Town, Catchment, Stormwater and River Management Branch.

BKS, 2001. Salt River Hydrological Study - Phase II. Liesbeeck River Hydrological Study. Report compiled for City of Cape Town, Catchment Stormwater and River Management Branch. 
de Villiers Sheard, 2002. Salt River Hydrological Study - Phase II. Blomvlei Canal Hydrological Study. Report compiled for City of Cape Town, Catchment, Stormwater and River Management Branch.

iCE Group, 2002. Salt River Hydrological Study - Phase II. Jakkasvlei Catchment. Report compiled for City of Cape Town, Catchment, Stormwater and River Management Branch.

KFD Wilkinson, 2001. Salt River Hydrological Study - Phase II. Black and Kromboom River Subcatchments. Report compiled for City of Cape Town, Catchment, Stormwater and River Management Branch.

Ninham Shand, 1993. Review of the April/May 1993 Storms over the Elsieskraal River Catchment. Report No 2060/4636. Report compiled for the Western Cape Regional Services Council.

Ninham Shand, 2000. Salt River Hydrological Study - Phase I. Report No 3004/8453. Report compiled for CMC Administration, Catchment Management Branch.

Ninham Shand, 2002. Salt River Hydrological Study - Phase II. Elsieskraal River Hydrological Study. Report No 3272/8453. Report compiled for City of Cape Town, Catchment, Stormwater and River Management Branch.

Pickard HWJ, 1968. Gentleman's Walk : The Romantic Story of Cape Town's Oldest Streets, Lanes and Squares. Struik Publishers, Cape Town, South Africa.

Schmidt M, 2003. Use of SWMM-EXTRAN for Bridges. SWMM-users list, 2003. Sigma Beta, 2000. Salt River Catchment Management Plan Formulation - Phase I. Report No 3108/8453. Report compiled for CMC Administration, Catchment Management Plan.

SESA, 1973, Salt River, C.P. Standard Encyclopaedia of South Africa, Vol 9. POPSLA. National Book Printers, Elsies River, Cape Town, South Africa.

Smithers and Schulze, 1987. Flood Volume and Peak Discharge from Small Catchments in Southern Africa, based on the SCS Technique. WRC Report No. TT 31/87. Water Research Commission. Pretoria. South Africa.

Smithers and Schulze, 2000. Long Duration Design Rainfall Estimates for South Africa. WRC Report No 811/1/00. WRC, Pretoria.

Smithers and Schulze, 2002. Estimation of Design Rainfall at Three Gauges in the Liesbeek Catchment, Western Cape Province. ACRUcons Report 37. University of Natal, Pietermaritzburg, South Africa. 